\title{
KEABSAHAN AKTA NOTARIL PERJANJIAN PENGIKATAN JUAL BELI DALAM PERALIHAN HAK ATAS TANAH
}

\author{
Wiwi Irmawati, Ayu Putriyanti, Anggita Doramia Lumbanraja \\ Program Studi Magister Kenotariatan \\ Fakultas Hukum, Universitas Diponegoro \\ E-mail: wiwiirmawati1@gmail.com
}

\begin{abstract}
Sale and purchase agreement is a preliminary agreement before buying and selling through the signing of sale and purchase certificate in front of the land deed official. However, there are still many people that will witness the validity of the transfer of right the deed of a binding purchase agreement. Validity and consequence of law for deed of sale and purchase agreement will be discussed. The research method uses doctrinal law by collecting data derived from literature and will analyze qualitatively to deduce the conclusion that is deductive. Base on research, the holder of the deed of the sale and purchase agreement has legal protection. The Deed that provides legal certainty because it refers to The Civil Code, Article 1876, and Law Of The Republic Of Indonesia Number 2 of 2014 concerning Of Notary Public's Figure. However, the provisions in this law were formed to protect the parties in entering into an agreement. Authentic deed made by a notary can be accounted for because the automatic deed has perfect proofing power that can prove itself, is formal and binds the parties who made it and can be used as evidence of the trial as an effort to protect the transfer of rights that have been done.
\end{abstract}

Key words : sale and purchase greement; notarial deed

\begin{abstract}
Abstrak
Perjanjian pengikatan jual beli merupakan bentuk perjanjian pendahuluan sebelum pengikatan jual beli melalui penandatangan akta jual beli dihadapan pejabat pembuat akta tanah. Namun masih banyak masyarakat yang menyangsikan keabsahan atas peralihan hak dengan akta perjanjian pengikatan jual beli. Sehingga permasalahan keabsahan dan akibat hukum akta perjanjian pengikatan jual beli yang dibuat secara notariil akan dibahas dalam tulisan ini. Metode penelitian dalam penulisan ini menggunakan metode hukum doktrinal dengan pengumpulan data yang berasal dari kepustakaan dan akan dianalisa secara kualitatif untuk diambil kesimpulan yang bersifat deduktif. Berdasarkan penelitian, pemegang akta perjanjian pengikatan jual beli memiliki perlindungan hukum dari negara. Akta yang dibuat dengan bentuk akta otentik memberikan kepastian hukum karena mengacu pada Kitab Undang-undang Hukum Perdata Pasal 1867 dan Undang-undang Negara Republik Indonesia Nomor 2 Tahun 2014 tentang Jabatan Notaris, dimana ketentuan-ketentuan dalam Undang-undang ini dibentuk untuk melindungi para pihak dalam melakukukan suatu perjanjian. Akta otentik yang dibuat oleh notaris dapat dipertanggung jawabkan karena akta otentik tersebut memiliki kekuatan pembuktian yang sempurna yang dapat membuktikan dirinya sendiri, bersifat formal serta mengikat para pihak yang membuatnya dan dapat dijadikan alat bukti dipersidangan sebagai upaya perlindungan terhadap peralihan hak yang telah dilakukannya.
\end{abstract}

Kata kunci : perjanjian jual beli; akta notaris 


\section{A. Pendahuluan}

Negara Indonesia adalah Negara hukum yakni negara yang dalam menjalankan roda pemerintahannya berlandaskan pada aturan hukum. Hukum dibuat untuk menciptakan keadilan dan kesejahteraan bagi rakyatnya. Oleh karena itu Negara hukum harus berlandaskan pada aturan hukun bukan pada kekuasaan belaka. Konsep negara hukum Indonesia berbeda dengan konsep negara anglo saxon maupun common law, konsep negara hukum Indonesia adalah konsep negara yang berlandaskan pada pancasila sebagai pandangan hidup bangsa. Sedangkan tujuan hidup bangsa Indonesia dituangkan dalam pembukaan dan Undang-undang Dasar Negara Republik Indonesia 1945 alinea keempat diantaranya yaitu memajukan kesejahteraan umum, mencerdasakan kehidupan bangsa, dan ikut melaksanakan ketertiban dunia yang berdasarkan kemerdekaan, perdamaian abadi dan keadilan sosial. (Undang Undang Dasar Negara Republik Indonesia Tahun 1945, n.d.) Subekti berpendapat bahwa hukum itu mengabdi pada tujuan negara yang dalam pokoknya ialah mendatangkan kemakmuran dan kebahagiaan pada rakyatnya. (Kansil, 1989)

Sebagai Negara hukum Indonesia membuat berbagai peraturan perundang-undangan yang bertujuan untuk memberikan kepastian hukum dan perlindungan bagi rakyatnya. Untuk melindungi kepentingan warga Negara dibidang pertanahan negara membuat Undang-undang pokok agraria diamana jaminan kepastian hukum sebagai wujud perlindungan terhadap masyarakat tercermin dalam Pasal 19 UUPA yang menyatakan bahwa : "Untuk menjamin kepastian hukum oleh pemerintah diadakan pendaftaran diseluruh wilayah Republik Indonesia menurut ketentuan-ketentuan yang diatur dengan peraturan pemerintah. (Undang-undang Nomor 5 tahun 1960 tentang peraturan Dasar Pokok-Pokok Agraria, n.d.) Sedangkan peraturan pemerintah yang berkaitan dengan pendaftaran tanah yaitu Pasal 3 PP Nomor 24 Tahun 1997 yang menyatakan bahwa tujuan dari pendaftaran tanah yaitu : (Peraturan Pemerintah Nomor 24 tahun 1997 tentang Pendaftaran Tanah, n.d.)

(1) Untuk memberikan kepastian hukum kepada pemegang hak atas suatu bidang tanah, suatu rumah susun dan hak-hak lain yang terdaftar agar dengan mudah dapat membuktikan dirinya sebagai pemegang hak yang bersangkutan.

(2) Untuk menyediakan informasi kepada pihak-pihak yang berkepentingan termasuk pemerintah agar dengan mudah dapat memperoleh data yang diperlukan dalam mengadakan perbuatan hukum mengenai bidang-bidang tanah dan satuan-satuan rumah susun yang sudah didaftar.

(3) Untuk terselenggaranya administrasi tertib pertanahan. 
Keberadan sertifikat sebagai tanda bukti hak merupakan wujud nyata dari kepastian hukum, dimana sertifikat merupakan tanda kepemilikan berisi data mengenai hak atas tanah yang dimiliki seseorang. Sebagaimana yang diungkapkan Widhi Handoko dalam bukunya bahwa: Secara hukum dengan berpegang pada alat bukti sertifikat, maka alat bukti tersebut akan berfungsi sebagai landasan yuridis formal yang dapat dipergunakan untuk melegalisasi asetnya."

Kepemilikan sertifikat hak atas tanah merupakan identitas yang berisi tentang riwayat tanah dan sangat berguna bagi pemegang haknya diantaranya dapat memberikan rasa aman atas tanah yang dimilikinya, memudahkan peralihan hak, memiliki harga jual yang lebih tinggi dan dapat dijadikan jaminan kredit. Namun kenyataan dilapangan masih banyak ditemukan kejanggalan-kejanggalan, hal ini terdeteksi ketika akan dilakukan peralihan hak atau akan dijadikan objek jaminan di bank. Banyak terdapat tanah masyarakat yang belum bersertifikat, bukti kepemilikan biasanya hanya berupa letter c, tanah warisan yang belum didaftarkan pemegang hak warisnya, dan sebagainya. Sehingga memerlukan waktu yang cukup panjang untuk merubah status maupun riwayat tanah, namun karena kebutuhan hidup manusia yang berbeda-beda terutama karena desakan ekonomi maka proses peralihan hak atau jual beli tetap dilaksanakan. Proses peralihan hak ini biasanya dilakukan dihadapan notaris yang diikat dengan perjanjian pengikatan jual beli. Keberadaan akta perjanjian pengikatan jual beli masih disangsikan keabsahannya oleh sebagian masyarakat.

Untuk mengupas masalah ini penulis menggunakan kerangka teori. Kerangka teori merupakan kerangka pikir yang intinya mencerminkan seperangkat proposisi yang berisi konstruksi pikir ketersalinghubungan atau kerangka pikir yang mencerminkan hubungan antar variabel penelitian.

Berdasarkan rumusan masalah dan kerangka konseptual yang telah penulis paparkan tersebut diatas, maka teori yang mendukung untuk menjawab permasalahan dalam penelitian ini adalah teori kepastian hukum dan teori perlindungan hukum. Teori kepastian hukum merupakan teori yang memandang secara konrit. Menurut J.C.T Simorangkir, hukum merupakan: "peraturan-peraturan yang bersifat memaksa, yang menentukan tingkah laku manusia dalam lingkungan masyarakat yang dibuat oleh badan-badan resmi yang berwajib, pelanggaran terhadap peraturan tadi berakibat diambilnya tindakan dengan hukuman tertentu" (Raharjo, 2016). Sedangkan, teori perlindungan hukum merupakan teori yang meletakan fokus kajiannya pada perlindungan hukum terhadap masyarakat. Perlindungan hukum menurut Satjipto Raharjo adalah "memberikan pengayoman terhadap hak asasi manusia (HAM) yang 
dirugikan orang lain dan perlindungan itu diberikan kepada masyarakat agar dapat menikmati semua hak-hak yang biberikan oleh hukum".(HS \& Nurbani, 2013)

Berdasarkan latar belakang diatas dengan disertai teori perlindungan hukum maka permasalahan yang akan dikaji dalam penelitian ini adalah bagaimana perlindungan hukum terhadap pemegang akta perjanjian pengikatan jual beli serta bagaimana keutamaan akta otentik dibandingkan dengan akta di bawah tanga serta apa sajakah keunggulan dari akta otenrik tersebut.

Tujuan penelitian ini diharapkan dapat memberikan informasi dan pemahaman bagi masyarakat terkait peralihan hak yang diikat dengan akta perjanjian pengikatan jual beli.

Penulisan tesis ini adalah hasil karya penulis sendiri. Peneliti melakukan perbandingan terhadap tiga penelitian yang telah dilakukan terdahulu oleh peneliti lainnya yakni diantaranya Arina Ratna Paramita yang mengkaji mengenai wanprestasi dalam perjanjian pengikatan jual beli tanah dan bangunan serta bagaimana penyelesaian penyelesaian wanprestasi dalam perjanjian pengikatan jual beli tanah dan bangunan tersebut (Paramitha, 2016). Riza Firdaus mengkaji mengenai kedudukan perjanjian pengikatan jual beli yang dibuat secara di bawah tangan menggunakan objek berstatus hak pengelolaan serta bagaimana perlindungan hukum bagi pembeli atas bangunan dan tanah yang masih berstatus hak pengelolaan (Firdaus, 2017). Lintang Yudhantaka mengkaji mengenai deskrisi keabsahan kontrak jual beli rumah susun dengan system pre project selling atau perjanjian pengikatan jual beli (Yudhantaka, n.d.).

\section{B. Metode Penelitian}

Penelitian dalam penulisan ini menggunakan metode pendekatan doktrinal dengan metode pengumpulan data dalam penelitian ini berasal dari data kepustakaan dan akan dianalisis secara kualitatif sedangkan kesimpulan dalam penelitian ini akan ditarik dengan metode deduktif.

\section{Hasil Dan Pembahasan}

\section{Perlindungan hukum terhadap pemegang akta perjanjian pengikatan jual beli}

Perjanjian pengikatan jual beli merupakan suatu perjanjian yang berkaitan dengan Buku III KUH Perdata tentang Perikatan (van verbintenissen) yang diatur dalam Pasal 1233 sampai dengan 1868 KUH Perdata. Namun jika merujuk dari beberapa ketentuan yang ada, Buku III sendiri tidak memberikan pengertian secara jelas apa yang dimaksud dengan perikatan. Pada dasarnya hukum perikatan menganut asas kebebasan berkontrak yang 
artinya setiap subjek hukum bebas untuk melakukan perjanjian sesuai dengan kehendak para fihak akan tetapi tidak boleh bertentangan dengan undang-undang, nilai kesusilaan dan ketertiban umum.

Konsep perikatan banyak ditafsirkan oleh para ahli diantaranya Subekti berpendapat bahwa: "perjanjian adalah suatu peristiwa dimana seorang berjanji kepada seorang lain atau dimana dua orang itu saling berjanji untuk melaksanakan sesuatu hal, maka timbulah suatu hubungan antara dua orang tersebut yang dinamakan perikatan."(Subekti, 2016) Sedangkan, Mariam Darus Badzrulzaman berpendapat bahwa : "Perikatan adalah hubungan yang terjadi diantara dua orang atau lebih yang terletak didalam lapangan harta kekayaan dimana pihak yang satu berhak atas prestasi dan pihak lain wajib memenuhi prestasi itu.(Busro, 2011)

Perjanjian pengikatan jual beli terwujud karena terjadinya suatu perjanjian sebagaimana diatur dalam Pasal 1313 Kitab Undang-undang Hukum perdata yang berbunyi "Suatu perjanjian adalah suatu perbuatan mana satu orang atau lebih mengikatkan dirinya terhadap satu orang atau lebih."(Subekti \& Tjitrosudibio, 2014) Artinya, perjanjian pengikatan jual beli lahir karena adanya perbuatan hukum antara pihak-pihak yang melakukan kesepakatan. Perjanjian tersebut baru dikatakan sah apabila memenuhi empat unsur pokok syarat sahnya perjanjian yang diatur dalam Pasal 1320 KUH Perdata yakni wajib adanya kesepakatan mereka yang mengikatkan diri, kecakapan untuk membuat suatu perikatan yang dimiliki oleh para subjek yang mengikatkan diri, adanya suatu hal tertentu yang menjadi objek perikatan dan adanya sebab yang halal yang tidak bertentangan dengan Undang-undang dan ketertiban umum.

Perjanjian pengiakatan jual beli merupakan perjanjian pendahuluan sebelum terjadinya perjanjian inti yang dituangkan dalam akta jual beli dengan tanah sebagai objek perikatannya. Peralihan hak atas tanah yang dituangkan dalam akta perjanjian pengikatan jual beli dilakukan karena berbagai alasan, diantaranya sertifikat masih dalam penguasaan fihak lain baik dalam jaminan bank maupun dalam proses pendaftaran tanah yang belum selesai di kantor pertanahan, pembayaran yang dilakukan secara bertahap dan kalusulaklausula lainnya yang dapat diperjanjikan. Jadi pada prinsipnya peralihan hak yang dilakukan dengan melakukan perjanjian pengikatan jual beli adalah peralihan hak yang bersifat sementara karena alasan-alasan yang ditentukan dalam perjanjian tersebut oleh penjual dan pembeli. Perjanjian pengikatan jual beli mengikat para pihak untuk sama-sama beritiad baik dalam hal melakukan transaksi jual beli tersebut walaupun belum secara langsung ditandatanganinya akta jual beli. Ketika pihak penjual dan pembeli menyatakan 
setuju tentang objek tanah dan harga, ketika itu pula jual beli terjadi dan mengikat secara sah bagi kedua belah pihak (Muhammad, 2011). Namun demikian ketentuan yang berkaitan dengan dokumen-dokumen pendukung seperti identitas para fihak, surat-surat pendukung bidang tanah, pembayaran pajak penjualan dan pembelian, serta mekanisme pelunasan atas bidang tanah tersebut harus tetap dilakukan sebagaimana mestinya.

Perjanjian Pengikatan jual beli pada hakikatnya dapat dilakukan secara dibawah tangan maupun dengan akta otentik, namun untuk menjamin keabsahan dan kepastian hukum hendaknya perjanjian jual beli dilakukan dengan menggunakan akta otentik dihadapan pejabat berwenang untuk itu. Pejabat yang berwenang untuk melakukan perjanjian pengikatan jual beli adalah notaris.

Berdasarkan Undang-undang Nomor 2 Tahun 2014 Perubahan Atas Undang-undang Jabatan Notaris Nomor 30 Tahun 2004 menyebutkan bahwa yang dimaksud dengan notaris adalah pejabat umum yang berwenang untuk membuat akta autentik dan memiliki kewenangan lainnya sebagaimana dimaksud dalam Undang-undang ini atau berdasarkan Undang-undang lainnya. Hal ini mengartikan bahwa notaris memiliki perintah langsung dari Undang-undang untuk membuat suatu akta otentik. Kemampuan notaris dalam menuangkan suatu bentuk perjanjian tidak perlu diragukan lagi, karena gelar notaris tidak didapatkan secara mudah, beberapa tahapan seperti telah lulus pascasarjana kenotariatan yang ditempuh kurang lebih selama dua tahun, dilanjutkan magang ditempat notaris yang telah berpraktek secara legal, lulus ujian kode etik serta mengikuti berbagai seminar hukum untuk mendapatkan pembaharuan ilmu, tak sedikit pula yang telah memiliki masa kerja belasan tahun sebelum menempuh pendidikan strata dua kenotariatan. Pengetahuan hukum progresif akan cakap memahami langkah-langkah yang harus ditempuh, lebih memahami kebutuhan masyarakat, dan menyesuaikan dengan kebijakan dan peraturan (Handoko, 2019). Oleh karena itu notaris memiliki kriteria yang dipandang Undang-undang pantas untuk diberikan amanat membuat akta otentik.

Akta otentik atau yang biasa disebut dengan akta notaris berdasarkan Undang-undang Jabatan Notaris Nomor 2 Tahun 2014 menyatakan bahwa "Akta notaris yang selanjutnya disebut akta adalah akta autentik yang dibuat oleh atau dihadapan notaris menurut bentuk dan tata cara yang ditetapkan dalam Undang-undang ini” (Undang Undang Republik Indonesia Nomor 2 Tahun 2014 tentang Perubahan Atas Undang-undang Nomor 30 tahun 2004 tentang Jabatan Notaris, n.d.). 
Akta otentikpun diatur secara jelas dalam Kitab Undang-undang hukum Perdata Pasal 1867 menyatakan bahwa "suatu akta otentik ialah suatu akta yang didalam bentuk yang ditentukan dalam undang-undang, dibuat oleh atau dihadapan pegawai-pegawai umum yang berkuasa untuk itu di tempat di mana akta itu dibuat (Subekti \& Tjitrosudibio, 2014).

Menurut A. Kohar akta otentik memiliki ciri-ciri sebagai berikut yaitu : akta dibuat dihadapan pejabat yang berwenang dan tercantum didalamnya kepastian tanggalnya, kepastian siapa yang menandatanganinya (legalitas identitas para pihak). Notaris telah menasihatkan sebelum akta dibuat mengenai isi akta (larangan dan perkenankan dilakukan). Apabila ada penyangkalan isi akta, maka penyangkalan itu harus dibuktikan. Akta notaris harus dirahasiakan oleh notaris (Kohar, 1983).

Penuangan perjanjian pengikatan jual beli yang dilakukan dengan membuat akta otentik dihadapan notaris adalah salah satu bentuk kepastian hukum yang akan memberikan keabsahan dan perlindungan hukum bagi para pihak yang melakukan perjanjian tersebut.

Ketentuan akta otentik tertuang dalam Pasal 1870 KUHPerdata yang menyatakan bahwa : "Suatu akta otentik memberikan diantara para pihak beserta ahli waris-ahli warisnya atau orang yang mendapat hak dari mereka, suatu bukti yang sempurna tentang apa yang dimuat didalamnya" (Subekti \& Tjitrosudibio, 2014). Hal ini mengandung konsekuensi bahwa perjanjian pengikatan jual beli yang dibuat dengan akta otentik memberikan nilai kepastian hukum, bahwa perjanjiannya benar-benar ditulis dan diakui keabsahannya secara hukum sehingga dapat dijadikan alat bukti yang kuat jikalau terjadi sengketa hukum. Jadi wujud otentiknya sebuah akta merupakan jaminan atas kepastian hukum.

Apabila nilai kepastian hukum sudah terpenuhi secara otomatis kepentingan masyarakat akan terlindungi. Sebagaimana Teori perlindungan hukum yang meletakan fokus kajiannya pada perlindungan hukum terhadap masyarakat.

Perlindungan hukum terdiri dari perlindungan yang bersifat preventif dan perlindungan yang bersifat refresif. Perlindungan hukum yang preventif merupakan perlindungan hukum yang bersifat pencegahan. Perlindungan memberikan kesempatan kepada rakyat untuk mengajukan keberatan (inspraak) atas pendapatnya sebelum suatu keputusan pemerintahan mendapat bentuk yang defenitif. Sehingga perlindungan hukum ini bertujuan untuk mencegah terjadinya sengketa dan sangat besar artinya bagi tindak pemerintah yang didasarkan pada kebebasan berindak (HS \& Nurbani, 2013). Contoh perlindungan secara refresif dapat dilihat apabila terjadi sengketa antara para pihak, maka pihak yang merasa dirugikan mengajukan gugatan diluar peradilan umum yaitu melalui badan penyelesaian konsumen (BPSK) yang berkedudukan di daerah tingkat II kabupaten 
dan kota di Indonesia. BPSK berperan sebagai mediator dalam penyelesaian sengkata jual beli diantara para pihak tersebut, BPSK akan menganalisis permasalahan, keputusan yang diambil merupakan keputusan mengikat dan final untuk para pihak, selain itu waktu penyelesaiannya singkat dan tidak memakan biaya.

Sedangkan, perlindungan hukum yang bersifat refresif adalah perlindungan yang bersifat tegas, keputusan yang dijatuhkan harus dilaksanakan oleh para pihak dan memiliki kekuatan eksekutorial. Apabila terjadi wanprestasi salah satu pihak dalam perjanjian jual beli, maka pihak yang dirugikan menempuh jalur peradilan umum dalam penyelesaian sengketanya. Hakim dalam peradilan umum akan menganalisis kasus dan menyelesaikan sesuai hukum acara`dalam peradilan umum, keputusan yang diambil merupakan keputusan yang memiliki kekuatan eksekutorial dan wajib dilaksanakan para pihak namun masih dapat dimungkinkan banding bagi pihak yang tidak puas dengan putusan tersebut. Akta perjanjian pengikatan jual beli merupakan bukti utama dalam pengambilan keputusan perkara oleh hakim. Salah satu contoh perlindungan secara preventif dapat diliat dalam amar putusan pengadilan tinggi Kota Bandung dengan register putusan nomor: 571/Pdt/2017/PT. BD. Pada tanggal 19 Pebruari 2018. Kasus diawali ketika terjadi perjanjian jual beli antara pembeli (tergugat) dengan penjual (penggugat) atas sebidang tanah yang diikat dengan akta perjanjian pengikatan jual beli (PPJB) yang dibuat di notaris di Depok. Dalam Akta Perjanjian jual beli disepakati bahwa pembeli akan membayar tanah tersebut dengan cara bertahap atau dicicil akan tetapi ditengah perjalanan pembeli tidak dapat memenuhi prestasinya sehingga dinyatakan wanprestasi oleh penjual. Atas wanprestasi tersebut penjual merasa dirugikan, oleh karena itu penjual melakukan gugatan ke Pengadilan Negeri di Depok. Pengadilan Negeri Depok memutuskan bahwa perjanjian pengikatan jual beli tersebut batal demi hukum. Karena tergugat tidak puas dengan putusan pengadilan tersebut maka melakukan banding pada tingkat pengadilan negeri di Bandung. Namun putusan pengadilan tinggipun menguatkan putusan pengadilan negeri semula sehingga perjanjian pengikatan jual beli karena adanya wanprestasi dinyatakan batal demi hukum.

\section{Akibat hukum peralihan hak yang diikat dengan akta perjanjian pengikatan jual beli.}

Akta perjanjian pengikatan jual beli yang dibuat oleh notaris merupakan akta pendahuluan yang berakibat hukum memiliki kekuatan pembuktian yang sempurna. Walaupun akta perjanjian pengikatan jual beli merupakan akta pendahuluan akan tetapi kekuatan akta tersebut dapat dijadikan landasan untuk melakukan peralihan hak secara 
langsung yakni penandatangan akta jual beli. Ketika semua hak dan kewajiaban telah dilaksanakan oleh para pihak sebagaimana yang telah diperjanjian dalam akta tersebut. Maka pihak pembeli secara pribadi dapat segera menemui pejabat pembuat akta tanah untuk melakukan peralihan hak tersebut tanpa kehadiran dari penjual.

Itikad baik merupakan landasan dasar terciptanya sebuah perjanjian akan tetapi karena suatu sebab tertentu sering kali terjadi wanprestasi. Bentuk wanprestasi dapat berupa salah satu pihak tidak memenuhi prestasinya, terlambat memenuhi prestasinya maupun memenuhi prestasi tapi tidak sesuai dengan yang diperjanjikan. Apabila salah satu pihak melakukan wanprestasi terhadap perjanjian pengikatan jual beli maka akta tersebut batal demi hukum. Dan pihak yang dirugikan dapat mengajukan gugatan berupa tuntutan pemutusan/pembatalan perjanjian, menuntut pemenuhan perjanjian, menuntut ganti rugi dan dapat mengajukan tuntutan pemenuhan sekaligus dengan ganti kerugiannya. Berhubung, akta perjanjian pengikatan jual beli dibuat dihadapan notaris maka cara penyelesain sengketa dapat dilihat dari klausula penyelesaian yang dituangkan dalam akta tersebut, apakah itu diselesaikan secara musyawarah ataukah melalui pengadilan negeri yang ditentukan oleh para pihak dalam akta tersebut. Dalam hal penyelesaian di pengadilan maka akta perjanjian pengikatan jual beli dapat dipergunakan sebagai alat bukti yang kuat dan sempurna karena akta otentik tersebut memiliki keistimewaan tidak seperti akta yang dibuat secara dibawah tangan. Keistimewaan tersebut diantaranya memiliki tanggal yang pasti, bentuk yang sesuai dengan Undang-undang karena dibuat oleh notaris sebagai pejabat yang berwenang dan isinya terjamin dari pemalsuan oleh pihak-pihak yang tidak bertanggung jawab, karena notaris tentunya memiliki warkah yang berisi tanda tangan langsung dari para pihak sebagai tanda kesepakatan atas perjanjian tersebut.

\section{Simpulan}

Akta perjanjian pengikatan jual beli adalah akta otentik yang dibuat dihadapan notaris sebagai bentuk perjanjian pendahuluan yang dijadikan dasar untuk mengikat para pihak dalam peralihan hak. Walaupun bentuknya masih bersifat akta notaris namun proses peralihan hak sudah memenuhi keabsahan hukum dan dapat melindungi pihak pembeli dari berbagai sengkata pertanahan. Wujud dari akta perjanjian pengikatan jual beli menunjukan adanya jaminan kepastian hukum dan sekaligus memberikan perlindungan hukum bagi para pihak yang membuatnya. Kepastian hukum yang diperoleh pemegang akta perjanjian pengikatan jual beli adalah bentuk konkritnya dari akta tersebut, berisi tentang hak dan kewajiban para pihak, objek 
jual beli serta beragam klausula yang disepakati yang dapat dijadikan bukti dalam persidangan apabila terjadi sengketa. Terpenuhinya jaminan kepastian hukum secara otomatis memberikan perlindungan hukum bagi para pihak. Substansi yang berisi hak dan kewajiban para pihak yang dituangkan dalam akta otentik menunjukan adanya itikad baik dari para pihak untuk melaksanakan hak dan kewajibannya masing-masing. Akta perjanjian jual beli menjadi pengantar untuk penandatangan akta jual beli yang dilakukan dihadapan pejabat pembuat akta tanah kemudian didaftarkan di kantor pertanahan setempat. Jadi walaupun perjanjian pengikatan jual beli masih dalam bentuk akta notaris pihak pembeli tidak perlu merasa khawatir karena sesungguhnya objek tanahnya sudah ada dalam kekuasaannya semenjak penandatangan akta perjanjian pengikatan jual beli tersebut dibuat. Akta pengikatan perjanjian jual belipun memiliki kekuatan pembuktian yang sempurna sehingga memberikan rasa aman serta manfaat bagi para pihak yang terkait. Perjanjian pengikatan jual beli yang dibuat dengan akta otentik memiliki berbagai keutamaan dibandingkan akta dibawah tangan.

\section{DAFTAR PUSTAKA}

\section{BUKU}

Busro, A. (2011). Hukum Perikatan Berdasarkan Buku III KUHPerdata. Yogyakarta: Pohon Cahaya.

Handoko, W. (2014). Kebijakan Hukum Pertanahan Sebuah Refleksi Keadilan Hukum Progresif. Yogyakarta: Thafa Media.

Handoko, W. (2019). Dominasi Negara Terhadap Profesi Notaris Antara Ide Dan Realitas. Bogor: Roda Publika Kreasi.

HS, S., \& Nurbani, E. S. (2013). Penerapan Teori Hukum pada Penelitian Tesis dan Disertasi. Jakarta: Raja Grafindo Persada.

Kansil, C. (1989). Pengantar Ilmu Hukum. Jakarta: Balai pustaka.

Kohar, A. (1983). Notaris dalam Praktek Hukum. Bandung: Alumni.

Muhammad, A. K. (2011). Hukum Perdata Indonesia. Bandung: PT. Citra Aditya Bakti.

Raharjo, H. (2016). Sistem Hukum Indonesia. 2016: Pustaka Yustisia.

Subekti, R. (2016). Hukum Perjanjian. Jakarta: PT. Internusa.

Subekti, R., \& Tjitrosudibio, R. Kitab Undang-undang Hukum Perdata. , (2014).

\section{ARTIKEL JURNAL}

Firdaus, R. (2017). Perlindungan Hukum Bagi Pembeli dalam Perjanjian Pengikatan Jual Beli 
Tanah yang masih Berstatus Hak Pengelolaan. Jurnal Hukum Lamlaj, 2(1).

Paramitha, A. R. (2016). Wanprestasi dalam Perjanjian Pengikatan Jual Beli Tanah dan Bangunan. Diponegoro Law Journal, 5 No.3.

Yudhantaka, L. (n.d.). Keabsahan Kontrak Jual Beli Rumah Susun dengan System Pre Project Selling. YURIDIKA, 32 No.1.

\section{UNDANG-UNDANG DAN PERATURAN}

KUHPerdata : Kitab Undang-undang Hukum Perdata ; Burgerlijk Wetboek. , (2007).

Undang-undang Nomor 5 tahun 1960 tentang peraturan Dasar Pokok-Pokok Agraria.

Undang Undang Dasar Negara Republik Indonesia Tahun 1945.

Undang Undang Republik Indonesia Nomor 2 Tahun 2014 tentang Perubahan Atas Undangundang Nomor 30 tahun 2004 tentang Jabatan Notaris.

Peraturan Pemerintah Nomor 24 tahun 1997 tentang Pendaftaran Tanah, n.d. 